\title{
Shared Anti-Idiotype-AB-S017
}

National Cancer Institute

\section{Source}

National Cancer Institute. Shared Anti-Idiotype-AB-S017. NCI Thesaurus. Code C29429.

A monoclonal antibody directed against a specific tumor-associated antigen (TAA).

$(\mathrm{NCl04})$ 